\title{
Analysis of energy balance and global warming potential in tangerine (Citrus tangerina Tanaka) orchards versus soybean (Glycine max (L.) Merr.) production system
}

\author{
Seyed Saeed HOSSEINI ${ }^{1}$, Hassan FEIZI ${ }^{*}$, Hamed KAVEH ${ }^{3}$, Hossein SAHABI ${ }^{3}$
}

Received August 25, 2020; accepted March 17, 2021. Delo je prispelo 25. avgusta 2020, sprejeto 17. marca 2021.

\begin{abstract}
Analysis of energy balance and global warming potential in tangerine (Citrus tangerina Tanaka) orchards versus soybean (Glycine max (L.) Merr.) production system

Abstract: With the aim of evaluation and comparison of the greenhouse gas emissions from soybean and tangerine production in Golestan province, Iran, a pilot experiment was carried out. In this experiment, 43 fields of soybeans and 43 orchard tangerines were selected by various management in the province using questionnaires. The greenhouse gas emissions were examined using the Global Warming Potential (GWP). The results of this study showed that fossil fuel was the highest energy consumption in the production of soybeans $(6906.5$ $\mathrm{MJ} \mathrm{ha}{ }^{-1}$ ) and tangerines (17205.1 $\mathrm{MJ} \mathrm{ha}^{-1}$ ). The lowest amount of energy consumption among inputs was related to micro fertilizers, that was $9 \mathrm{MJ} \mathrm{ha}^{-1}$ for soybeans and 17.6 $\mathrm{MJ} \mathrm{ha}^{-1}$ for tangerine. In both of production system, the most energy consumed was shown for the harvesting sector. Irrigation and planting were the highest contributors to greenhouse gas emissions in soybean field by 387.7 and $109.4 \mathrm{~kg} \mathrm{CO}_{2} \mathrm{ha}^{-1}$, respectively; while in the tangerine production, the most greenhouse gas emissions were related to irrigation and harvesting process by 5828.4 and $394.7 \mathrm{~kg} \mathrm{CO}_{2} \mathrm{ha}^{-1}$. In general, input energy in soybean and tangerine were 17512.8 and $33879.8 \mathrm{MJ} \mathrm{ha}^{-1}$, total output energy was calculated 48310.5 and $105463 \mathrm{MJ} \mathrm{ha}^{-1}$. Finally, the energy use efficiency was computed for soybean and tangerine 2.9 and 3.3, respectively.
\end{abstract}

Key words: tangerine; soybean; energy use efficiency; greenhouse gas emissions
Primerjalna analiza energetske bilance in potenciala globalnega segrevanja med pridelovalnima sistemoma sadovnjakov mandarin (Citrus tangerine Tanaka) in gojenjem soje (Glycine $\max (\mathrm{L}$.$) Merr.)$

Izvleček: Z namenom ovrednotenja in primerjave emisij toplogrednih plinov med pridelavo soje in mandarin je bil $\mathrm{v}$ provinci Golestan, Iran, izveden pilotni poskus. Za poskus je bilo z vprašalnikom izbranih 43 polj soje in 43 sadovnjakov mandarin $\mathrm{z}$ različnimi načini upravljanja. Emisije toplogrednih plinov so bile preučene $\mathrm{z}$ uporabo protokola potencialnega globalnega segrevanja (GWP). Rezultati so pokazali, da je predstavljala uporaba fosilnih goriv največjo porabo energije, tako pri soji $\left(6906,5 \mathrm{MJ} \mathrm{ha}^{-1}\right)$ kot pri mandarinah $\left(17205,1 \mathrm{MJ} \mathrm{ha}^{-1}\right)$. Najmanjši energetki vložek pri gojenju obeh kultur so predstavljala mikrohranila, $9 \mathrm{MJ} \mathrm{ha}^{-1}$ pri soji in 17,6 $\mathrm{MJ} \mathrm{ha}^{-1}$ pri mandarinah. $\mathrm{V}$ obeh sistemih pridelave je bilo največ energije porabljene za spravilo pridelka. Pri pridelavi soje sta prispevala največji delež emisije toplogrednih plinov namakanje in setev, 387,7 in 109,4 $\mathrm{kg} \mathrm{CO}_{2} \mathrm{ha}^{-1}$, med tem, ko sta pri pridelavi mandarin $\mathrm{k}$ temu prispevala največ namakanje in spravilo pridelka, 5828,4 in 394,7 $\mathrm{kg} \mathrm{CO}_{2}$ ha $^{-1}$. Na splošno je bil energetski vložek pri pridelavi soje 17512,8 in pri pridelavi mandarin $33879,8 \mathrm{MJ} \mathrm{ha}^{-1}$. Celokupen izplen energije je bil pri soji 48310,5 in pri mandarinah $105463 \mathrm{MJ} \mathrm{ha}^{-1}$. Izračunana učinkovitost izrabe energije je bila za sojo 2,9 in za mandarine 3,3.

Ključne besede: mandarine; soja; učinkovitost izrabe energije; emisije toplogrednih plinov

\footnotetext{
Former MSc Student, Department of Plant Production, University of Torbat Heydarieh, Iran.

2 Associate Professor, Department of Plant Production, University of Torbat Heydarieh, Torbat Heydarieh, Iran.

3 Assistant Professor, Department of Plant Production, University of Torbat Heydarieh, Torbat Heydarieh, Iran.

* Corresponding author: Hassan Feizi, E-mail: h.feizi@torbath.ac.ir
} 


\section{INTRODUCTION}

In the agricultural sector, energy consumption has increased over the last several decades due to population growth, decrease in arable land and improvement of living standards. To feed a growing population, intensive use of chemical fertilizers, pesticides, agricultural machines, electricity and natural resources is needed (Barut et al., 2010). Fossil resources are limited and, proper and high-efficiency use is necessary to preserve these resources for future generations of humans. On the other hand, the increased intensive use of energy sources causes environmental problems (Alluvione et al., 2011). Unfortunately, most of the time farmers use more energy to increase crop production, but they do not have enough knowledge on how to increase the efficiency of energy consumption (Ozkan et al., 2004). Therefore, it is not possible to analyze the input and output energies in production systems to design agronomic and policy-making models in agricultural sales sector without examining the efficiency of energy consumption. Energy relationships in agricultural production are correlated with production techniques, inputs, yield levels, and environmental factors. Given that energy consumption and environmental problems resulting from agriculture are increasing year by year, efficient energy consumption is therefore an important issue in sustainable agriculture (Singh et al., 1997). On the other hand, calculating energy inputs in agriculture is more difficult than in industrial sectors because many controllable and uncontrollable factors affect production.

In these days, the agricultural methods are toward developing systems that can generate more energy with lower input consumption (Dalgaard, 2000; Tzilivakis et al., 2005). Increasing energy efficiency and reducing greenhouse gas emissions in crop production are among the fundamental issues in achieving sustainable production (Dyer and Desjardins, 2003). Aydin (2019) stated that the largest share of input energy in the production of tangerines in Turkey with $36 \%$ is associated with the use of chemical fertilizers and the total input energy was estimated at $42.3 \mathrm{GJ} \mathrm{ha}^{-1}$.

In the year 2017, out of about 2.85 million hectares of the orchards in Iran, about 818 thousand hectares, or $28.7 \%$, were allocated to subtropical fruits. Among the 7.7 million tons of tropical fruit production in the country, about $10 \%$ was related to tangerine production. Golestan province is one of the northern provinces of Iran. The area under cultivation of crops in this province is 724697 hectares, out of which 694618 hectares are for agricultural crops and the rest for orchards. Golestan province is one of the most important areas for citrus production in the country. According to the Ag- ricultural Jihad Statistics of 2017, citrus cultivation area in Golestan province has been reported at 6500 hectares, which has been allocated to cultivation of tangerine, orange and bitter orange. The total area under cultivation of tangerine in Iran was 43525 hectares with production of about 757000 tons in 2017. The area under cultivation in Golestan province was 1549 hectares and produced 20217 tons (Ministry of Agriculture, 2018).

According to the Statistics and Information Office of the Ministry of Agriculture Jihad, Iran, the total area under soybean cultivation in Iran in the year 2017 was about 40000 hectares that, 91000 tons of soybean have been produced from this area. The area under soybean cultivation in Golestan province has been 21000 hectares where 41000 tons of grain has been produced. Golestan province, with $45 \%$ of total grain production, is in the first place of soybean production in the country (Ministry of Agriculture, 2018).

Considering the fact that more than $45 \%$ of the country's soybean is cultivated in Golestan province also, due to the abundance of citrus orchards in the province, study of the energy and greenhouse gas emissions of the two soybean and tangerine products and comparing them together to identify the factors and methods with the maximum energy use in producing these crops seem necessary. This will help agricultural policy makers in the pattern of cultivation in different regions to guide farmers to cultivate tangerine or to grow soybean. These results will also help farmers decide whether to establish tangerine orchards or soybean farms.nally, a risk assessment for consumers was conducted.

\section{MATERIAL AND METHODS}

\subsection{DATA COLLECTION}

For this research, 43 soybean fields and 43 tangerine orchards were selected in villages of Golestan province in Gorgan, Bandar Turkmen, Kordkouy, Fazelabad and Aliabad. The farms and orchards were selected in a way to cover all soybean and tangerine production management in the area.

For this purpose, a questionnaire was designed and data were collected through personal (face-to-face) interviews with farmers and taking notes of various field operations. In these farms and orchards, information on duration of field operations, amount of fuel consumed for each operation, machines used, number of conduction of each operation, cultivar and amount of seed consumed, type and amount of fertilizer consumed, name and amount of herbicides and insecticides, irrigation duration, irrigation water supply location, energy used 
for pumping water (diesel or electricity) and orchard and field yields were recorded. In order to collect information on the type and amount of inputs and all input and output energies, the number of samples was obtained from the following (Eq.1) (Newbold, 1994):

$$
n=N \times S^{2} /(N-1) S^{2} x+S^{2}
$$

where $n$ is the required sample size, $N$ is population size, $S$ is standard deviation, $S_{X}$ is standard deviation of sample mean $\left(S_{X}=d / z\right), d$ is the allowable error in the sample size was defined to be $5 \%$ of the mean for a $95 \%$ confidence interval and $z$ is the reliability coefficient (1.96 which represents the $95 \%$ reliability).

\subsection{ENERGY CALCULATION}

Energy flows in farms and orchards can be divided into two types of input energy and output energy. To calculate the input energy in the farms and orchards, the energy inputs were first calculated. Finally, the amount of energy output was calculated by measuring the yield of seed and fruit produced. In order to calculate the amount of input energy for each of the soybean and tangerine sectors, apart from the energy used by the machines and the energy resulted by the electricity consumption, the consumption rate of each input (human labor in hour per hectare, fertilizer in kilograms of nutrients consumed per hectare per kilogram of effective ingredient per hectare) is multiplied by their energy equivalent. The energy equivalent for each of the inputs used and the soybean and tangerine seeds produced have been presented in Table 1.

\subsection{CALCULATION OF ENERGY INDICES}

The following equations were used to calculate each of the energy indices (Eq. 2-5) (Ghorbani et al., 2011):

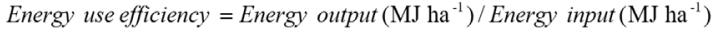

\subsection{ESTIMATES OF GREENHOUSE GAS EMIS- SIONS}

Global Warming Potential (GWP) Index was used to evaluate the greenhouse gas emissions. This index is the sum of the greenhouse gases produced, expressed as carbon dioxide equivalent (IPCC, 1997). In order to calculate GWP emissions, three greenhouse gases of carbon dioxide, nitrous oxide and methane resulting from energy consumption were considered to produce agricultural inputs and perform various agricultural and horticultural operations.

The GWP was calculated during the following steps:

1. The energy equivalent for the production and use of each of the inputs as well as the energy equivalent for each crop production for soybean and tangerine were calculated according to the method described in the energy section.

2. The share of different energy sources used, including electricity, natural gas, diesel, oil and petroleum, was estimated for the production of each of the inputs (Green, 1987; Tzilivakis et al., 2005). The amount of electricity, natural gas, diesel, oil and petroleum determined by the questionnaires was multiplied at the equivalent energy and its energy equivalent was calculated.

3. After determining the contribution of each energy source to the production of different inputs, the emission rate of each of greenhouse gases of carbon dioxide, methane and nitrous oxide resulting from the use of different energy sources by using greenhouse gas emission factors for each joule of energy consumed was calculated separately for each energy source.

4. Given the different potential of greenhouse effect for the three carbon dioxide, methane and nitrous oxide gases (each $\mathrm{kg}$ of nitrous oxide and methane have 310 and $21 \mathrm{~kg}$ carbon dioxide of greenhouse effect, respectively), total greenhouse gas emissions was calculated as carbon dioxide equivalent, which is the GWP index.

5. After calculating the total GWP, GWP values per unit area $\left(\mathrm{kg} \mathrm{CO}_{2}\right.$ eq per hectare) per yield unit produced ( $\mathrm{kg} \mathrm{CO}$ eq per ton of soybeans) were calculated per unit of energy input ( $\mathrm{kg} \mathrm{CO}$ eq in Giga-Joule) and in units of output energy ( $\mathrm{kg} \mathrm{CO}_{2}$ eq in Giga-Joule).

\subsection{STATISTICAL ANALYSIS}

In this study, SAS (Ver. 9.2) and Excel software were employed for data analysis and drawing the graphs. 
Table 1: Energy equivalents of inputs and outputs in tangerine orchard and soybean field

\begin{tabular}{|c|c|c|c|}
\hline Particulars & Unit & $\begin{array}{l}\text { Energy equivalent } \\
\quad\left(\mathrm{MJ} \text { unit }^{-1}\right)\end{array}$ & Reference \\
\hline \multicolumn{4}{|l|}{ Inputs } \\
\hline Human labor & $\mathrm{h}$ & 1.96 & Ozkan et al. (2004) \\
\hline Machinery & $\mathrm{h}$ & 142.7 & Kaltsas et al. (2007) \\
\hline Diesel fuel & 1 & 38.00 & Ministry of oil (2007) \\
\hline Nitrogen & $\mathrm{kg}$ & 60.60 & Akcaoz et al. (2009) \\
\hline Phosphate $\left(\mathrm{P}_{2} \mathrm{O}_{5}\right)$ & $\mathrm{kg}$ & 11.10 & Akcaoz et al. (2009) \\
\hline Potassium $\left(\mathrm{K}_{2} \mathrm{O}\right)$ & $\mathrm{kg}$ & 6.70 & Akcaoz et al. (2009) \\
\hline Insecticide & $\mathrm{kg}$ or & 237 & Tzilivakis et al. (2005) \\
\hline Herbicides & $\mathrm{kg}$ or $\mathrm{l}$ & 278 & Tzilivakis et al. (2005) \\
\hline Manure & $\mathrm{kg}$ & 0.30 & Taylor et al. (1993) \\
\hline Electricity & $\mathrm{kWh}$ & 3.60 & Pimental and Pimental (1996) \\
\hline Irrigation Water & $\mathrm{m}^{3}$ & 0.63 & Taylor et al. (1993) \\
\hline Seed & $\mathrm{kg}$ & 30.50 & Pimental and Pimental (1996) \\
\hline \multicolumn{4}{|l|}{ Outputs } \\
\hline Grain yield & $\mathrm{kg}$ & 15.05 & Pimental and Pimental (1996) \\
\hline Fruit & $\mathrm{kg}$ & 1.9 & Kitani (1999) \\
\hline
\end{tabular}

\section{RESULTS AND DISCUSSION}

\subsection{FUEL CONSUMPTION RATE DURING OPERATIONS}

Among the various soybean operations, fertilization had the lowest amount of diesel consumption, averaging 1.15 liters per hectare (Table 2). The highest fuel consumption in soybean production was related to irrigation operations that consumed, on average, 81.1 liters per hectare (diesel) for diesel wells and $972 \mathrm{kWh}$ per hectare of electricity energy for electric wells (Table 2). After irrigation, the highest fuel consumption in soybean production was related to harvesting operations, which averaged 32.4 liters per hectare (Table 2). One thing to note about fuel consumption and operation is that the way of the operations also affects fuel consumption. For example, land preparation with combine harvester consumes less fuel than land preparation with a plow and a deep farm disk (Table 2).

Regarding the production of tangerines, the highest fuel consumption was for harvesting operations, which consumed an average of $157.8 \mathrm{l} \mathrm{ha}^{-1}$. After harvesting, the highest fuel consumption in the tangerine production process was related to the irrigation operation, which consumed an average of $126.1 \mathrm{l} \mathrm{ha}^{-1}$ (Table 2). The lowest amount of fuel consumed in the tangerine produc- tion operation was associated with weed control, pest control, which consumed an average of 9.8 and $15.5 \mathrm{l}$ $\mathrm{ha}^{-1}$, respectively. It should be noted, however, that the chemical fertilization operation had no fuel consumption because it was fully manned (Table 2 ). Weed control also had high fuel consumption in relation to the production of tangerines such as animal manure, in a way that animal manure consumed an average of 38.1 liters of fuel per hectare and weed control consumed an average of $42.1 \mathrm{l} \mathrm{ha}^{-1}$ (Table 2). Yilmaz and Aydin (2019) stated that the highest share of input energy in the production of tangerines in Turkey with $36 \%$ is associated with the use of chemical fertilizers and the total input energy was estimated at $42.3 \mathrm{GJ} \mathrm{ha}^{-1}$.

\subsection{ENERGY CONSUMPTION IN THE INPUTS SECTOR}

Based on the results of Table 3, the energy consumption rate per seed input varied from 948.1 to $752.5 \mathrm{MJ}$ $\mathrm{ha}^{-1}$, so that the average soybean fields studied in this experiment consumed 840.7 MJ ha-1 per seed (Table 3). Among the fertilizers used for soybean production, nitrogen fertilizer had the highest energy consumption, with the highest energy consumption for nitrogen fertilizer at $6363 \mathrm{MJ} \mathrm{ha}^{-1}$. As some of the fields studied did not use nitrogen fertilizer, the lowest energy consumption for 
Table 2: Amount of used gasoline $\left(\mathrm{l} \mathrm{ha}^{-1}\right)$ and electricity $\left(\mathrm{kWh} \mathrm{ha}^{-1}\right)$ for each operation in tangerine orchard and soybean field

\begin{tabular}{lcc}
\hline Operation & Tangerine & Soybean \\
\hline Land Preparation & $30.7 \pm 5.2$ & $15.5 \pm 2.5$ \\
Sowing & $27.3 \pm 3.2$ & $7.4 \pm 1.1$ \\
Fertilization and manure & $38.1 \pm 3.3$ & $15.1 \pm 2.0$ \\
Pest control & $15.5 \pm 1.2$ & $19.4 \pm 3.6$ \\
Weed control & $9.8 \pm 1.2$ & $3.8 \pm 0.3$ \\
Irrigation & $126.1 \pm 9.2$ & $81.1 \pm 6.6$ \\
Harvesting & $157.8 \pm 6.9$ & $32.4 \pm 3.2$ \\
Land operation & $14.7 \pm 2.8$ & 0 \\
Total & $19.8 \pm 420.0$ & $12.3 \pm 174.7$ \\
Electricity for irrigation & $1113 \pm 114.5$ & $972 \pm 59.6$ \\
\hline
\end{tabular}

Table 3: Consumed energy (MJ ha' ${ }^{-1}$ ) for different input of tangerine orchard and soybean field

\begin{tabular}{lcc}
\hline Input & Tangerine & Soybean \\
\hline Labor & $2312.5 \pm 116.7$ & $535.5 \pm 88.5$ \\
Seed / Seedling & $2533.0 \pm 145.3$ & $840.7 \pm 2.2$ \\
Machinery & $11910.6 \pm 791.8$ & $3754.9 \pm 881.6$ \\
Fuel & $17205.1 \pm 1050.8$ & $6906.5 \pm 391.2$ \\
Electricity & $1156.1 \pm 548.1$ & $269.2 \pm 86.4$ \\
Nitrogen & $1087.8 \pm 102.3$ & $3878.4 \pm 115.9$ \\
Phosphorus & $1063.7 \pm 81.2$ & $1041 \pm 102.2$ \\
Potassium & $391.9 \pm 59.3$ & $251.2 \pm 39.2$ \\
Micro nutrient & $17.6 \pm 1.2$ & $9 \pm 1.1$ \\
Herbicide & $204.6 \pm 10.7$ & $88.9 \pm 10.2$ \\
Pesticide & $206.9 \pm 9.0$ & $36.3 \pm 2.1$ \\
Winter pest control & $56 \pm 8.6$ & - \\
Manure & $187 \pm 19.8$ & - \\
Total & 38332.8 & 17611.6 \\
\hline
\end{tabular}

fertilizers was zero, so the average energy consumption for nitrogen fertilizer was $3878.4 \mathrm{MJ} \mathrm{ha}^{-1}$ (Table 3). In the case of phosphorus and potash fertilizer, because some farms did not use these two types of fertilizer, the lowest energy consumption for potassium and phosphorus fertilizer was zero (Table 3). The average consumption of phosphorus and potassium fertilizers for soybean production was 1041 and $252.2 \mathrm{MJ} \mathrm{ha}^{-1}$, respectively (Table 3 ). In the studied farms, the amount of fertilizer consumed depends on the management of the farms and the finances of the farmers. Generally, in the Gorgan area, the farms who consider the crop rotation and have planted legumes in the fall and also in the case of returning crop residues to the soil, the farmers do not use nitrogen and potash fertilizers without affecting crop yields.
Also, farmers who did not have high financial resources refused to use fertilizer to reduce production costs, the opposite was also true, farmers who had relatively good financial status used micro-fertilizers in addition to common fertilizers.

Regarding tangerines, the average energy consumption for nitrogen, phosphorus and potassium fertilizer inputs for tangerine production were estimated at 1087.7, 1063.7 and 391.9 MJ ha ${ }^{-1}$, respectively (Table 3). Maximum energy consumption for nitrogen, phosphorus and potassium fertilizer inputs was 1087.8, 1063.72775 and 391.9 $\mathrm{MJ} \mathrm{ha}^{-1}$, respectively (Table 3 ). An average energy of $187 \mathrm{MJ} \mathrm{ha}^{-1}$ has been consumed in the studied orchards in relation to livestock manure (Table 3 ). Among the herbicide, pesticide and winter spraying inputs, the 
highest amount was related to pesticide $206.9 \mathrm{MJ} \mathrm{ha}^{-1}$, after the pesticide input, the herbicide input with the highest energy consumption of 204.6 $\mathrm{MJ} \mathrm{ha}^{-1}$ had the highest energy consumption for tangerine production.

Dehshiri and Aghaalikhani (2012) reported the average energy use in soybean seed production in Golestan and Mazandaran was $1836 \mathrm{MJ} \mathrm{ha}^{-1}$. Rajabi et al. (2012) reported an average energy consumption of $5964 \mathrm{MJ} \mathrm{ha}^{-1}$ for wheat production. In their study, the researchers calculated the highest and lowest energy consumption of this input, respectively at 1248 to $12366 \mathrm{MJ} \mathrm{ha}^{-1}$. Mousavi Aval et al. (2011) estimated the amount of energy consumed by nitrogen, phosphorus, potassium, and sulfur fertilizers for soybean production in Gorgan, at 6281, 627,102 , and $4 \mathrm{MJ} \mathrm{ha}^{-1}$, respectively. The difference in the energy consumption rate in the fertilizer sector in this study was in line with other studies in the Golestan province due to the recent increase in fertilizer prices that farmers preferred to use less fertilizer to reduce production costs. In soybean production studies, the energy consumption of herbicides for soybean production in the Golestan region has been estimated at $631 \mathrm{MJ} \mathrm{ha}^{-1}$.

In the production of tangerines, the average energy consumed for human labor was 2312.5 MJ ha-1 (Table 3). Like soybeans, the way in which various operations are performed has a huge impact on the amount of energy consumed in the tangerine sector, for example, the irrigation method can affect the energy consumption rate of the work force sector. Drip irrigation did not have any human labor, while flood irrigation of the orchards required a great deal of work force and consumed a great deal of energy in the work force sector. Yilmaz and Aydin (2019) reported that the highest energy consumption in the orchards of tangerine and lemon production was associated with the use of chemical fertilizers and fuel.

\subsection{CONSUMPTION ENERGY FOR VARIOUS OPERATIONS IN SOYBEAN AND TANGERINE PRODUCTION}

The results of Table 4 showed that among the various operations for soybean production, the highest average energy consumption was related to harvesting with average value of $2955 \mathrm{MJ} \mathrm{ha}^{-1}$ (Table 4). The lowest average energy consumption in the soybean production process was related to manual weeding, cultivator and hoeing, which consumed 62.3 and 107.0 $\mathrm{MJ} \mathrm{ha}^{-1}$ on average (Table 4). The average energy consumption in land preparation, irrigation, sowing and fertilization in soybean production was estimated at 556.4, 543.3, 1115.2 and 1755.6 $\mathrm{MJ} \mathrm{ha}^{-1}$, respectively (Table 4 ).
In the process of tangerine production, the highest average energy consumption is related to the harvesting process (picking the fruit and transporting it to the desired location) which is significantly different with other operations in energy consumption, so that, on average, 13817.6 $\mathrm{MJ} \mathrm{ha}^{-1}$ energy is consumed for the tangerine harvesting operations (Table 4). In fact, the tangerine harvesting process consumes a lot of energy because of the human labor. On the other hand, because of the high fruit yield in the tangerine orchards, the energy for transport is also very high. These are two factors could raise energy consumption for the tangerine harvesting operation. It should be noted, however, that the energy consumption rate in tangerine harvesting operations largely depends on the proximity or location of the storage or sale of tangerines, which also increases with increasing destination distance.

After harvesting, the highest energy consumption was related to irrigation operations with an average value of 5763.9 MJ ha-1 in tangerine production (Table 4). Fertilization also had less tangerine energy consumption of on average 1098.99 $\mathrm{MJ} \mathrm{ha}^{-1}$ than the other operations (Table 4). In terms of comparing soybean and tangerine energy consumption, it should be stated that energy consumption in tangerine production is very different from soybean, for example, the energy consumption rate in soybean irrigation is on average $543.3 \mathrm{MJ} \mathrm{ha}^{-1}$, while this amount for tangerine was $5763.9 \mathrm{MJ} \mathrm{ha}^{-1}$ (Table 4). In general, it can be stated that the energy consumption of similar operations in soybean production is much lower than that of tangerine production, which could also be due to the presence of tangerines throughout the year.

Filipović et al. (2006) estimated fuel consumption for three types of tillage systems including conventional tillage, low tillage and direct tillage at 71, 35 and 7.5 liters per hectare, respectively. Mari and Changying (2007) compared conventional tillage, low tillage and direct tillage systems in terms of fuel and energy consumption and showed the highest energy consumption (7969 MJ ha-1) in fuel consumption for the conventional system and the lowest energy consumption (4099 $\mathrm{MJ} \mathrm{ha}^{-1}$ ) for direct cropping system. Farmers and orchardist can reduce production costs by reducing fuel consumption (Tabatabaeefar et al., 2009).

\subsection{ENERGY USE INDICATORS}

Table 5 presents the energy inputs, outputs, as well as energy indicators of soybean and tangerine production. Total input energy in soybean production was on average $17512.8 \mathrm{MJ} \mathrm{ha}^{-1}$ (Table 5). Soybean yield was on average $3210 \mathrm{~kg} \mathrm{ha}^{-1}$, the lowest and highest grain yield 
Table 4: Consumed energy $\left(\mathrm{MJ} \mathrm{ha}^{-1}\right)$ in different operations of tangerine orchard and soybean field

\begin{tabular}{lcc}
\hline Operation & Tangerine & Soybean \\
\hline Sowing & $2173.6 \pm 99.6$ & $1115.2 \pm 58.6$ \\
Land preparation & $2533.0 \pm 95.2$ & $556.4 \pm 41.6$ \\
Fertilization & $1098.9 \pm 45.2$ & $1719.2 \pm 115.4$ \\
Pest control & $3139.5 \pm 148.6$ & $216.6 \pm 11.6$ \\
Weeding & $906.4 \pm 74.5$ & $62.3 \pm 8.4$ \\
Irrigation & $5763.9 \pm 188.2$ & $543.3 \pm 18.1$ \\
Harvest & $13718.6 \pm 521.2$ & $2955 \pm 156.5$ \\
Cultivator and hoeing & $2180.7 \pm 113.2$ & $107.0 \pm 15.2$ \\
\hline Total & 31513.8 & 7275.0 \\
\hline
\end{tabular}

in the studied soybean fields were 2700 and $3800 \mathrm{~kg} \mathrm{ha}^{-1}$, respectively. The total energy output for soybean fields was on average $48310.5 \mathrm{MJ} \mathrm{ha}^{-1}$ (Table 5).

The net energy produced in the studied soybean fields was 30797.7 MJ ha ${ }^{-1}$ on average (Table 5). The energy efficiency index in the studied fields was 2.9 on average. The energy efficiency index is obtained by dividing the total output energy by the total input energy in soybean fields. This index indicates that the output energy in the farms is several times the input energy, in the soybean fields the energy efficiency index ranged from 1.8 to 5.5. The energy productivity index in soybean fields was at $5.5 \mathrm{t} \mathrm{GJ}^{-1}$ on average, the energy efficiency index is obtained by dividing the grain yield by the input energy values of the soybean fields. This indicator shows the ratio of grain yield to input energy in the field. In our investigation it varied between 8.1 to $2.7 \mathrm{t} \mathrm{GJ}^{-1}$. The higher energy efficiency index causes the higher yield for less input energy.

In the soybean fields, the specific energy index was at $0.19 \mathrm{GJ} \mathrm{t}^{-1}$ on average. The specific energy index is the opposite of the energy efficiency index and is obtained by dividing the input energy by soybean grain yield. Net energy performance index calculated from subtraction of output energy and input energy is in fact the same amount of net energy which was $30.8 \mathrm{GJ} \mathrm{ha}^{-1}$ on average for the soybean field (Table 5).

But in the tangerine orchards studied, the average energy input for all orchards was $33879.8 \mathrm{MJ} \mathrm{ha}^{-1}$ (Table 5). The average tangerine yield in orchards was 56033.3 $\mathrm{kg} \mathrm{ha}^{-1}$, with the highest and lowest tangerine yields of 80000 and $37000 \mathrm{~kg} \mathrm{ha}^{-1}$, respectively (Table 5). The average total energy output in the orchards under study was 105463.3 MJ ha ${ }^{-1}$. The net energy in the studied orchards varied between 129213.1 $\mathrm{MJ} \mathrm{ha}^{-1}$ to 29629.4 $\mathrm{MJ} \mathrm{ha}^{-1}$, with an average net energy value of $72583.5 \mathrm{MJ} \mathrm{ha}^{-1}$ in the studied orchards (Table 5).

Energy efficiency index of tangerine orchards was
3.3 on average. The highest energy use efficiency was 6.7 and the lowest energy efficiency index was 1.6. Average energy use efficiency in tangerine production was higher than soybean production, this indicates that tangerine orchards produce more net energy than soybean fields, but a very important point is that the soybean production process in Gorgan is about half the length of the growing season, while tangerine orchards have been occupied by tangerine trees throughout the growing season, it is therefore reasonable to expect less net energy in soybean fields than in tangerine orchards (Table 5).

Energy efficiency index in tangerine orchards was on average $0.63 \mathrm{GJ} \mathrm{t}^{-1}$ (Table 5). The average net energy yield index in the tangerine orchards under study was $72.5 \mathrm{GJ} \mathrm{ha}^{-1}$ (Table 5). Yilmaz and Aydin (2019) by examining the energy balance in citrus orchards reported the energy efficiency in tangerine orchards at 2.03, the energy yield at $0.85 \mathrm{~kg} \mathrm{MJ}^{-1}$, the net energy at $1.18 \mathrm{MJ}$, and the net energy at $43.6 \mathrm{GJ} \mathrm{ha}^{-1}$, respectively. In the overall comparison between tangerine and soybean, total input energy in soybean production was much lower than in tangerine production. Also, the total energy output and net energy in soybean were also lower than those of soybean. The net energy output for soybean production was 30797.7 MJ ha-1, but it was estimated at 72583.5 $\mathrm{MJ} \mathrm{ha}^{-1}$ for tangerine, this indicates a much higher output of tangerine than soybean. Comparison results between energy indices in soybean and tangerine production showed that energy efficiency index in soybean (2.9) was lower than tangerine (3.3), but energy productivity in soybean (5.5) was higher than tangerine (1.3). In addition, net yield energy index in soybean was $30.8 \mathrm{GJ} \mathrm{ha}^{-1}$, which was much lower than net energy index in tangerine (72.5 GJ ha $\left.{ }^{-1}\right)$ (Table 5).

Ozalp et al. (2018) showed that the input energy of pomegranate in Turkey was $50.5 \mathrm{GJ} \mathrm{ha}^{-1}$ and the output energy was 76.3 GJ. The energy use efficiency was also 1.51. Aydin et al. (2018) stated that in the apple produc- 
Table 5: Input, output and energy indexes of tangerine orchard and soybean field

\begin{tabular}{lccc}
\hline Index & Unit & Tangerine & Soybean \\
\hline Total Input & $\mathrm{MJ} \mathrm{ha}^{-1}$ & $33879.8 \pm 688$ & $17512.8 \pm 596$ \\
\hline Fruit/Seed Yield & $\mathrm{kg} \mathrm{ha}^{-1}$ & $56033.3 \pm 791$ & $3210 \pm 256$ \\
Total output & $\mathrm{MJ} \mathrm{ha}^{-1}$ & $105463.3 \pm 822$ & $48310.5 \pm 671$ \\
Net energy & $\mathrm{MJ} \mathrm{ha}^{-1}$ & $72583.5 \pm 511$ & $30797.7 \pm 822$ \\
Energy use efficiency & - & $3.3 \pm 0.9$ & $2.9 \pm 0.3$ \\
Energy productivity & ton GJ $^{-1}$ & $1.3 \pm 0.2$ & $5.5 \pm 0.6$ \\
Specific energy & $\mathrm{GJ} \mathrm{t}^{-1}$ & $0.63 \pm 0.07$ & $0.19 \pm 0.03$ \\
Net yield energy & $\mathrm{GJ} \mathrm{ha}^{-1}$ & $72.5 \pm 5.3$ & $30.8 \pm 3.6$ \\
\hline
\end{tabular}

tion system with good agricultural method, energy efficiency, energy yield and specific energy were $1.36,0.56$ and 1.77, respectively. In a study, Ghorbani et al. (2011) compared energy consumption in dry land wheat (low input) and irrigated wheat (high input). They stated that the total energy consumption in dryland wheat cultivation was 9354.2 MJ/ha, but the total energy input in irrigated wheat was 45367.6 $\mathrm{MJ} \mathrm{ha}^{-1}$. Sahabi et al. (2013) stated that the input energy for wheat and barley production was 514040 and $44866 \mathrm{MJ} / \mathrm{ha}$, respectively. They stated that profit-to-cost ratio in wheat was higher than in barley, which was 1.59 versus 1.35 . Generally speaking, lower consumption of inputs can reduce energy consumption in the production of horticultural products but it should be noted that the decrease in inputs does not have a negative effect on the profit-to-cost ratio.

\subsection{GREENHOUSE GAS EMISSIONS}

\subsubsection{Emissions of greenhouse gases from consump- tion of inputs}

The results of the study of greenhouse gas emissions in the fields and orchards under study for different inputs have been presented in Fig. 1. The results of soybean field surveys showed that the highest greenhouse gas emission rate was related to fuel and electricity inputs with the average values of respectively 501.6 and $163.7 \mathrm{~kg}$ of $\mathrm{CO}_{2}$ per hectare. The lowest values for greenhouse gas emission rate in the soybean fields were in human labor and pesticide, respectively, which produced, on average, 0.22 and $0.78 \mathrm{~kg} \mathrm{CO}$ per hectare, respectively (Fig. 1). The average greenhouse gas emission rate was higher for herbicides than for pesticides, because most of the farms used herbicides, this led to a higher energy consumption for herbicides than for pesticides.

In the production of tangerines like soybeans, the highest greenhouse gas emission rate was related to fuel input, which produced an average $1249.6 \mathrm{~kg}$ of $\mathrm{CO}_{2}$ per hectare (Fig. 1). The average greenhouse gas production rate for tangerine input was lower than for pesticides, this is because fruit trees are more susceptible to pests and diseases than weeds, which is why most of the orchards studied used pesticides, and another reason is that some of the orchards under study used cultivators instead of herbicides to combat weeds (Fig. 1). Ozalp et al. (2018) showed that 1.73 tons of $\mathrm{CO}_{2}$ was emitted in the production of one hectare of pomegranate. An $88.1 \mathrm{~kg}$ of $\mathrm{CO}_{2}$ is also emitted to produce $1000 \mathrm{~kg}$ of fruit.

The average greenhouse gas emissions induced from human labor for tangerines were $11.79 \mathrm{~kg} \mathrm{CO}_{2}$ on average per hectare, which was much higher than for soybeans. This seems to be due to the large amount of human labor being used in harvesting in tangerines and so the greenhouse gas emissions in the tangerine human labor sector are also increasing. In the production of tangerine manure fertilizer also caused a significant greenhouse gas emissions, averaging $78.5 \mathrm{~kg} \mathrm{CO}_{2} \mathrm{ha}^{-1}$ (Fig. 1). In general, it can be said that greenhouse gas emissions are much higher in the production process of tangerines than soybeans, so, in similarly used inputs between soybean production and tangerine, greenhouse gas emissions were higher in tangerine (Fig. 1).

\subsubsection{Released greenhouse gases resulting from agri- cultural and horticultural operations}

Different amounts of greenhouse gases are produced in different operations to produce soybeans and tangerines, which have been summarized in Fig. 2 .

According to the results of Figure 2 in the soybean production process, the highest amount of greenhouse gas emissions was produced in irrigation operations, which was on average at $387.7 \mathrm{~kg} \mathrm{CO}_{2} \mathrm{ha}^{-1}$ (Fig. 2). Harvesting and irrigation were the operations that cause 


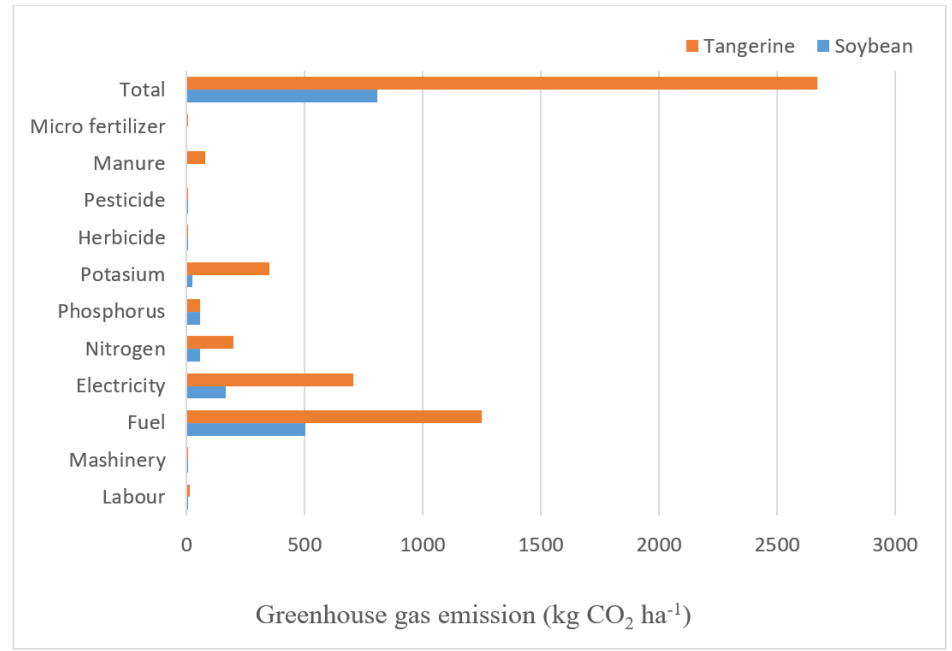

Figure 1: Amount of greenhouse gas emission ( $\mathrm{kg} \mathrm{CO}_{2}$ per hectare) for different inputs in tangerine and soybean production systems

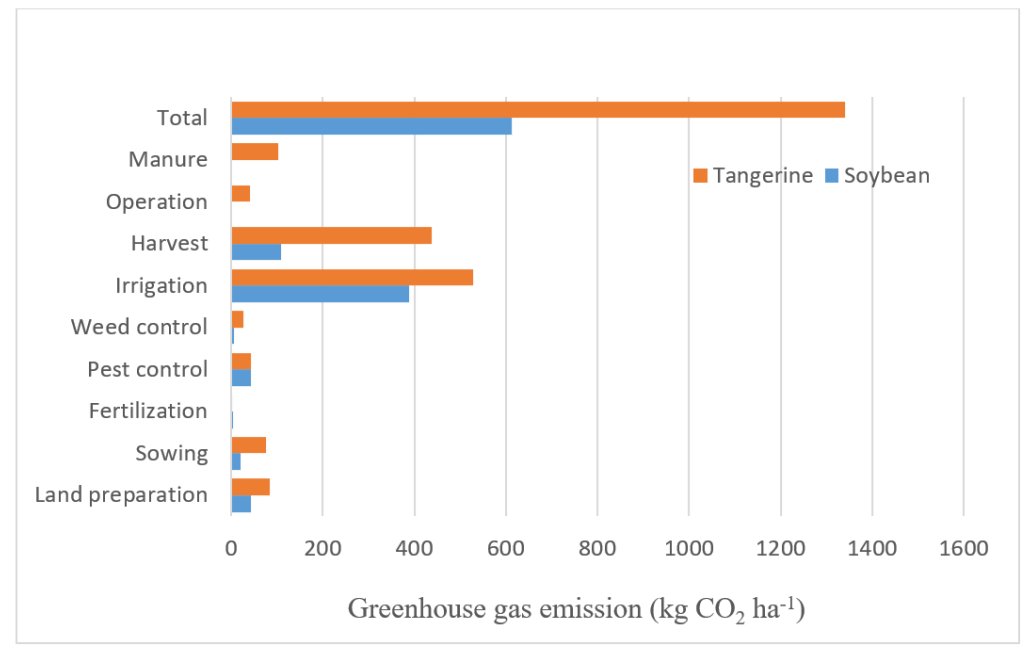

Figure 2: Amount of greenhouse gas emission $\left(\mathrm{kg} \mathrm{CO}_{2} \mathrm{ha}^{-1}\right)$ for different operations in tangerine and soybean production systems

most important greenhouse gas emissions to produce tangerines in the orchards under study. These two irrigation and harvesting operations have, on average, released 528.4 and $439.7 \mathrm{~kg} \mathrm{CO}_{2} \mathrm{ha}^{-1}$ of greenhouse gas, respectively. Greenhouse gas emissions in different tangerine production operations showed that these operations produced more greenhouse gases than similar operations in soybean production, in fact, it should be stated that the amount of greenhouse gas emission derived from fuel consumption, human labor and etc. in tangerine production was higher than soybean. This ultimately produces more greenhouse gases in the tangerine production process (Fig. 2).

The average carbon emissions for soybean production for conventional tillage, low-tillage and no-tillage systems were reported at 168,146 , and $137 \mathrm{~kg} \mathrm{CO}_{2} \mathrm{ha}^{-1}$, respectively (West and Marland, 2002).

\section{CONCLUSION}

In general, the results showed that the total energy consumed per hectare of tangerine orchard far exceeds the energy required for soybean production. This difference is mainly due to the high fruit production rate per hectare and therefore the high energy needed to harvest and transport it. In tangerine production system irrigation also consumed more energy than soybeans. In soybean production, the highest energy consumption was associated with irrigation and harvesting operations. The greenhouse gas emission rate in citrus production was 
higher comparing to soybean production because of fuel consumption and human labor, which in the end has led to the production of more greenhouse gases in the tangerine production process. Considering the fact that in the management of the orchards, farmer has to carry out different operations throughout the year because this plant is a perennial plant compared to a soybean plant which is annual and farming operations are conducted in only a part of the year. In addition, because of the much higher crop production in tangerine orchards, so energy consumption and carbon dioxide emissions are much higher in tangerine orchards. Thus farmers can use the findings of this study to decide whether to establish a tangerine or soybean farm in terms of energy balance and carbon dioxide production. However, economic, social, climatic, and edaphic comparisons are also needed to make more precise decisions.

\section{ACKNOWLEDGMENTS}

This research has been supported with University of Torbat Heydarieh, Torbat Heydarieh, Iran. Hereby we appreciate vice president of education and research, University of Torbat Heydarieh for support of this study.

\section{REFERENCES}

Akcaoz H., Ozcatalbas O., Kizilay H. (2009). Analysis of energy use for pomegranate production in Turkey. Journal of Food Agriculture Environment, 7, 475-480.

Alluvione F., Moretti B., Sacco D., Grignani C. (2011). EUE (energy use efficiency) of cropping systems for a sustainable agriculture. Energy, 36, 4468-4481. https://doi.org/10.1016/j. energy.2011.03.075

Aydın B., Aktürk D., Ozkan E., Hurma H., Kiracı M. A. (2018). Comparative energy use efficiency and economic analysis of apple production in Turkey: Case of Thrace Region. Erwerbs-Obstbau, 61, 39-45. https://doi.org/10.1007/s10341018-0387-5

Barut Z. B., Ertekin C., Karaagac H.A. (2011). Tillage effects on energy use for corn silage in Mediterranean Coastal of Turkey. Energy, 36, 5466-5475. https://doi.org/10.1016/j. energy.2011.07.035

Dalgaard T. (2000). Farm types-how can they be used to structure, model and generalize farm data? In: Agricultural Data for Life Cycle Assessments. Weidema B.P, Meeusen M.J.G. (Eds.), Report 2.00.01. Agricultural Economics Research Institute, The Hague, The Netherlands, 98-114.

Dehshiri A., Aghaalikhani M. (2012). Input-output and economic analysis of soybean production in the main cultivation areas in Iran. African Journal of Agricultural Research, 7, 4894-4899. https://doi.org/10.5897/AJAR12.010
Dvoskin D., Nicol K., Heady E.O. (1976). Irrigation energy requirements in the 17 western states. In: Agriculture and energy. Lockeretz W. (Eds.). New York: Academic: 103- 112. https://doi.org/10.1016/B978-0-12-454250-1.50013-7

Dyer J.A., Desjardins R.L. (2003). The impact of farm machinery management on greenhouse gas emissions from Canadian agriculture. Sustainable Agriculture, 20, 59-74. https://doi.org/10.1300/J064v22n03_07

Filipovic D., Kosutić S., Gospodarić Z., Zimmer R., Banaj D. (2006). The possibilities of fuel savings and the reduction of $\mathrm{CO}_{2}$ emissions in the soil tillage in Croatia. Agriculture Ecosystem and Environment, 115, 290-294. https://doi. org/10.1016/j.agee.2005.12.013

Ghorbani R., Mondani F., Amirmoradi S., Feizi H., Khorramdel S., Teimouri M., Sanjani S., Anvarkhah S., Aghel H. (2011). A case study of energy use and economical analysis of irrigated and dryland wheat production systems. Applied Energy, 88, 283-288. https://doi.org/10.1016/j.apenergy.2010.04.028

Green M. (1987). Energy in pesticide manufacture, distribution and use. In: Energy in plant nutrition and pest control, Helsel Z.R., (Eds.). Amsterdam: Elsevier, 165-177.

Intergovernmental Panel on Climate Change (IPCC). (2007). Intergovernmental Panel on Climate Change WGI, Fourth Assessment Report, Climate Change 2007: The Physical Science Basis. Summary for Policymakers. IPCC Secretariat, c/o WMO, 7bis, Avenue de la Paix, C.P.N. 2300, 1211 Geneva 2, Switzerland.

Kaltsas A. M., Mamolos A. P., Tsatsarelis C. A., Nanos G.D., Kalburtji K.L. (2007). Energy budget in organic and conventional olive groves. Agriculture Ecosystem and Environment, 122, 243-251. https://doi.org/10.1016/j. agee.2007.01.017

Kitani O. (1999). CIGR Handbook of Agricultural Engineering. Energy and Biomass Engineering, ASAE publication.

Lal R. (2004). Carbon emission from farm operations. Environment International, 30, 981- 990. https://doi.org/10.1016/j. envint.2004.03.005

Mari G. R., Changying J. (2007). Energy analysis of various tillage and fertilizer treatments on corn production. Journal of Agricultural Environment Science, 2, 486-497.

Ministry of Agriculture. (2018). Iran annual agricultural statistics. Ministry of Jihad-e-Agriculture of Iran. www.maj.ir.

Ministry of Petrolium. (2007). Country hydrocarbon balance sheet. Ministry of Oil. Iran. (In Persian)

Mousavi Avval S. H., Rafiee S., Jafari A., Mohammadi A. (2011). Improving energy productivity of sunflower production using data envelopment analysis (DEA) approach. Journal of Science Food Agriculture, 91, 1885-1892. https://doi. org/10.1002/jsfa.4403

Newbold P. (1994). Statistics for Business and Economics. Prentice-Hall, Inc.

Ozkan B., Akcaoz H., Fert C. (2004). Energy input -output analysis in Turkish agriculture. Renewable Energy, 29, 3951. https://doi.org/10.1016/S0960-1481(03)00135-6

Ozalp A., Yilmaz S., Ertekin C., Yilmaz I. (2018). Energy Analysis and emissions of greenhouse gases of pomegranate production in Antalya Province of Turkey. Erwerbs-Obstbau, 60, 321-329. https://doi.org/10.1007/s10341-018-0380-z 
Pimental D., Pimental M. (1996). Food, Energy and Society. Boulder, CO: Colorado University Press.

Rajabi M. H., Soltani A., Zeinali E., Soltani E. (2012). Evaluation of greenhouse gas emission and global warming potential in wheat production in Gorgan, Iran. Electronical Journal Crop Production, 5(3), 23-44.

Sahabi H., Feizi H., Amirmoradi S. (2013). Which crop production system is more efficient in energy use: wheat or barley? Environment Development Sustainability, 15, 711-721. https://doi.org/10.1007/s10668-012-9402-4

Singh S., Mittal J. P., Verma S. R. (1997). Energy requirements for production of major crops in India. Agricultural mechanization in Asia, Africa and Latin America, 28, 7-13.

Tabatabaeefar A., Emamzadeh H., GhasemiVarnamkhasti M., Rahimizadeh R., Karimi M., (2009). Comparison of energy of tillage systems in wheat production. Energy, 34, 41-45. https://doi.org/10.1016/j.energy.2008.09.023
Taylor E. B., O’Callaghan P. W., Probert S. D. (1993). Energy audit of an English farm. Applied Energy, 44, 315-35. https:// doi.org/10.1016/0306-2619(93)90022-H

Tzilivakis J., Warner D.J., May M., Lewis K. A., Jaggard K. (2005). An assessment of the energy inputs and greenhouse gas emissions in sugar beet (Beta vulgaris) production in the UK. Agricultural Systems, 85(2), 101-119. https://doi. org/10.1016/j.agsy.2004.07.015

West T. O., Marland G. (2002). A synthesis of carbon sequestration, carbon emissions, and net carbon flux in agriculture: comparing tillage practices in the United States. Agriculture Ecosystem Environment, 91, 217-232. https://doi. org/10.1016/S0167-8809(01)00233-X

Yilmaz H., Aydin B. (2019). Comparative input-output energy analysis of citrus production in Turkey: Case of Adana province. Erwerbs-Obstbau, 62, 29-36. https://doi.org/10.1007/ s10341-019-00447-z 